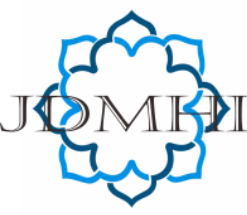

email: jdmhi@walisongo.ac.id

Journal of Digital Marketing and Halal Industry

ISSN: 2716-4810 (print) ISSN: 2716-4802 (online)

\title{
The Effect Of Usability Perception And Easy Perception Of Real Use In Online Purchasing Transactions
}

\author{
Surya Adi Rahman', Fajar Adhitya ${ }^{2}$, Novan Erlandika ${ }^{3}$ \\ ${ }^{1}$ Sekolah Tinggi Ilmu Ekonomi BPD Semarang, Indonesia \\ 2,3 Faculty of Islamic Economics and Business, Islamic State University of Walisongo Semarang, Indonesia
}

\section{A R T I C L E I N F O}

\section{Article history:}

Received 06 Desember 2019

Received in revised form 16 Januari 2020

Accepted 16 Januari 2020

Keywords:

perceived usefulness, perceived ease of use, intention to use, actual usage system

\begin{abstract}
A B S T R A C T
This study aims to determine instagram users in the needs of product purchase transactions by including variables of perceived usefulness, perceived ease of use, intentin to use and actual usage system. The sample used in this study is Instagram users who have made product purchases through Instagram among Semarang students, the number of respondents is 65 students. This study uses multiple linear regression analysis method. From the results of this study indicate that directly variable perceived usefulness, perceived ease of use influence directly actual usage system and indirectly directly perceived usefulness, perceived ease of ose influence directly to actual usage system through intention to use.
\end{abstract}

\begin{abstract}
A B S T R A K
Penelitian ini bertujuan untuk mengetahui pengguna Instagram dalam mrnggunakan transaksi pembelian produk dengan meliputi variabel persepsi kegunaan, persepsi kemudahan, variabel penggunaan nyata dan variabel minat. Sampel yang digunakan dalam penelitian ini adalah pengguna Instagram yang sudah pernah melakukan transaksi pembelian produk melalui Instagram di kalangan mahasiswa Kota Semarang, jumlah responden 65 Mahasiswa. Penelitian ini menggunakan metode analisis regresi linier berganda. hasil penelitian menunjukan bahwa secara langsung variabel persepsi kegunaan, persepsi kemudahan berpengaruh secara langsung terhadap penggunaan nyata dan secara tidak langsung persepsi kegunaan, persepsi kemudahan berpengaruh secara langsung terhadap penggunaan nyata melalui minat menggunakan.
\end{abstract}

\footnotetext{
* Corresponding author. email: Suryaadirahman25@gmail.com http://dx.doi.org/10.21580/jdmhi.2019.1.1.4760
} 


\section{Introduction}

Online business or the usual business is called e - Commerce currently being available in many countries and one in Indonesia, this is due to the Internet development and the change of consumer behavior. The easy Internet access or gadgets is easier to access the public to access any product of products or services that he's carrying into his gender is promoted by the company or certain businesses of the company or the projects of his services or his services.

Indrajit (2001: 2), one of the typical textice is consisting of two parties's deals; there are no luggage exchange, services, or information and Internet as the major media in transaction. The e - commerce transaction in the league can happen between the business institution with a fellow business Institute (b2b) and between the business organization with consumers (b2c). E - Commerce was first introduced in $1994 \mathrm{~s}$ the first time banner electronic used for promotion and advertising on web pages.Every year, an advanced, a vitalized vassdiction is monitored. This year wearesocialvywho works samavwith hootsuite back global global Digital report in 2018 which shows many amazing numbers of the world. The slight call that tvindonan came in there and there was some interesting stuff.

Graph 1. Diagram of Growth of Social Media Users

\section{Diagram Pertumbuhan}

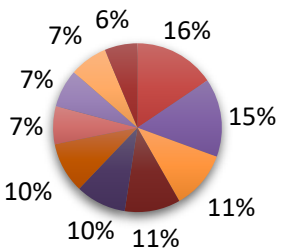

According to the data above states that in the growth of social media users in Indonesia experienced a growth of $23 \%$. Based on the ranking of Indonesia ranks third after India and Saudi Arabia, this shows the increase in Indonesia's ranking in 2017 which ranked fourth.Based on the previous explanation, to see how the actual conditions regarding the use of Instagram among Semarang City students were carried out pre-survey by distributing a temporary questionnaire to 67 students. From the average results of the questionnaire distributed it can be concluded that most students have the attraction to make a purchase of a product through Instagram. Purchasing products online through Instagram is widely used by users because it does not interfere with activities and does not take time and does not cost more in shopping online. Instagram also has several features that can be useful for finding the desired product quickly, one of which is the hashtag, with these features there will be many choices of products sought. This is what makes Instagram users use it to make purchases online. Currently Instagram has many updates to provide uses for its users so as to make users more comfortable in using the application.

Davis (1989) in his book Technology Acceptance Model explains that usability and convenience are the main things in determining the interest in using and actually using the information technology system. Davis (1989) The use of technology is believed to bring benefits to people who use it and can be operated easily and the tendency of behavior to keep using a technology, Davis (1989). The level of use of a computer technology on a person can be predicted from the attitude of the user's attention to the technology, for example the 
desire to add peripherals that support, the motivation to keep using it, and the desire to motivate other users. Real use which is the real condition of system use, Davis (1989). Individuals will be satisfied using the system if they believe that the system is easy to use and can increase their productivity, which is reflected in the real conditions of use.

Based on the background described above, the issue arises whether Instagram is used for online purchases for its users, researchers are interested in conducting a study entitled "Analysis of the Effects of Perception of Usability and Perception of Ease of Real Use with Interest in Using as Intervening Variables in Online Purchase Transactions in Semarang City Students ".

\section{Literature Review}

\section{Instagram}

There are several factors that cause the communication behavior of active users of Instagram, which are supporting facilities, the desire to produce better works, high frequency of access and encouragement from relatives, Nugraha (2012) in Wida (2017). Communication behavior between active Instagram users is uploading photos, following and unfollowing, giving likes and comments, affixing information on uploaded photos and attending gathering and photowalk activities, Nugraha (2012). The meaning and function of Instagram is as a medium for making photos and sending them in a very fast time. Instagram is a photo sharing application that allows users to take photos, apply digital filters, and share them to various social networking services, including Instagram's own, Novianti, et al (2017).

\section{Technology Acceptance Model (TAM)}

Technology Acceptance Model is one model that was built to analyze and understand the factors that influence the acceptance of the use of computer technology, Davis (1980). TAM is the result of the development of the Theory of Reasoned Action (TRA). This theory is a reasonable action with a premise that a person's reaction and perception of something, will determine the person's attitude and behavior with two constructs, namely perceived ease and perceived usefulness, Fishbein \& Ajzen (1975).

\section{Perception of Ease}

The definition of perceived ease is a level where a person believes that the use of certain systems can reduce one's efforts in doing something. Meaningfulness without difficulty or unnecessary effort, Davis (1989). This perception of convenience refers to the user's belief that the technology system used does not require huge effort when used According to Hartono (2007: 115). Perceived ease is defined as the extent to which a person believes that using technology will be free of effort. Perceived ease of use is based on the extent to which prospective users expect the new system to be used free from difficulties. This explanation is supported by Wibowo (2006) who explains that a perception of ease of use of technology is defined as a measure by which someone believes that the technology is easy to understand and easy to use.

\section{Interest in using}

Interest in using TAM is defined as a behavioral tendency to keep using a technology, Davis (2000). The level of use of a computer technology in a person can be predicted from the attitude of the user's 
attention to the technology, for example the desire to add supporting peripherals, the motivation to keep using it, and the desire to motivate other users. Interest in using is the level at which someone consciously plans to do or not do specific behaviors in the future.

Interest is the behavioral intention of users to use information systems, so it becomes a behavioral tendency to continue to use the information system, Endang Fatmawati (2015) in Novianti Astrid Widya, et al (2017). From the explanation above, it can be concluded that the notion of interest in using is the desire of someone to use a technology in the presence of factors to support the behavior. The level of use of a computer technology on someone can be predicted from the attitude and attention of the user of the technology.

\section{Real Use}

Real use is a real behavior in adopting a system. Real use is defined as a form of external psychomotor response as measured by someone with real use, Davis (1989). Real use is conceptualized in the form of measurements of the frequency and duration of time of technology use, Wibowo (2006). Someone will have the satisfaction of using the system if they believe the system is easy to use, increasing productivity, which is reflected in the real conditions of its use.

Someone will be satisfied using the system if that person believes that the system is easy to use and will increase the productivity of their performance, which is reflected in the real condition of the user. The form of real usage measurement is the frequency and duration of time. Use of ICTs. The actual use of technology, measured by the amount of time spent interacting with the technology and the frequency of use of the technology, Khakim (2011). Furthermore Hanggono, et al. (2015) divides technology acceptance into four indicators namely: comfort to interact, like to use, enjoy usage, and not boring. Can be concluded the definition of real use someone will feel happy to use the system if they believe that the system is not difficult to use and proven to increase their productivity, which is reflected in the real conditions of use. Can be concluded the definition of real use someone will feel happy to use the system if they believe that the system is not difficult to use and proven to increase their productivity, which is reflected in the real conditions of use.

1. Selwendri \& Rumyeni (2016), Wida Putu Ayu Mira Witriyanti (2016) in her research found that there is a positive and significant relationship between perceived usefulness and real use. This is evidenced by someone who feels that a system is useful then also increases the intensity of its users. This means that the benefits provided by Instagram have resulted in an increase in adoption of online purchase transaction services

2. Positive and significant relationship between the perceived ease of use and the actual usage system found in Selwendri \& Rumyeni (2016) research, Wida Putu Ayu Mira Witriyanti (2016), in her research results on the use of Intagram stated the various facilities provided by Instagram to users have an impact positive that makes Instagram users increase.

3. Positive and significant relationship between perceived usefulness and 
interest in using is also found in research Novianti Astrid Widya, et al (2017). Usability perception variable significantly influences the use interest in Telkom University Faculty of Economics and Business Students. In promoting online shopping, sellers need a strategy that brings a positive perception of the benefits of Instagram social media, so that it brings a positive impact on consumers.

4. The research results of Hanggono Aditya Arie, et al (2015) show that the interest in using TAM has a positive effect on real use. This means that the higher the tendency of students to use Instagram, the higher the reality of their use.

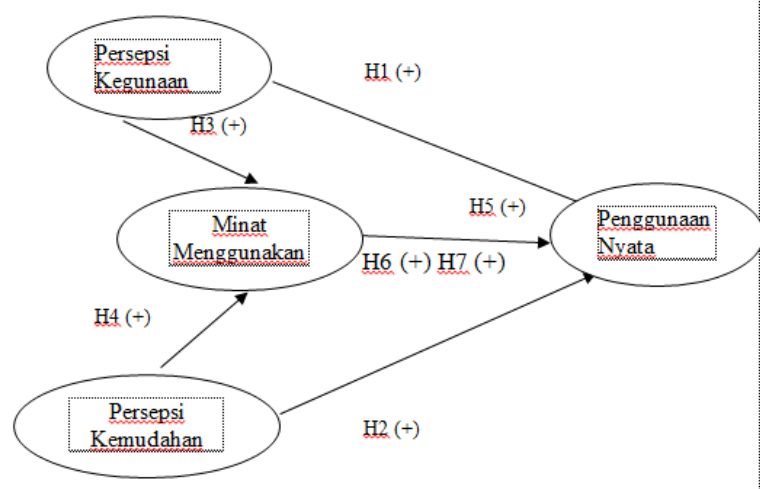

\section{Theoretical Framework and Hypothesis}

Hypothesis 1: Perception of Use has a positive effect on Instagram's Real Use in Online Purchase Transactions.

Hypothesis 2: Ease of Perception has a positive effect on Instagram's Real Use in Online Purchase Transactions.

Hypothesis H3: Perception of Use has a positive effect on Interest in Using Instagram in Online Purchase Transactions.

Hypothesis H4: Ease of Perception has a positive effect on Interest in Using Instagram in Online Purchase Transactions.

Hypothesis 5: Interest in using positively influences Instagram's Real Use in Online Purchase Transactions.

Hypothesis 6: Perception of Use has a positive effect on Real Use with Interest in Using as Intervening Variables

Hypothesis 7: Ease Perspectives have a positive effect on real use through interest in using as intervening variables.

\section{Method, Data, and Analysis}

\section{Types of research}

This study uses a quantitative approach, which is an approach that emphasizes testing theories or concepts through measurement of variables in metrics or numbers and performs data analysis procedures with statistical equipment and aims to test hypotheses.

\section{Independent Variable}

According to Sugiyono (2016: 39), the Independent Variable / Independent variable is the independent variable $(\mathrm{X})$ This variable is often referred to as a stimulus, predictor, and antecedent variable. In Indonesian it is often referred to as the independent variable. The independent variable is the variable that influences or is the cause of the change or the appearance of the dependent variable (dependent) Independent or independent variables. The independent variables used in this study are perceived usefulness and perceived convenience. 


\section{Dependent Variable}

According to Sugiyono (2016: 39), Dependent Variables / Bound Variables are variables that are affected or are the result, because of the independent variables. The dependent variable used in this study is real use. Intervening Variable. According to Sugiyono (2016: 39), Intervening Variables are variables that theoretically affect the relationship between independent and dependent variables into an indirect relationship and cannot be observed and measured. This variable is an interim variable between the independent and dependent variables, so that the independent variable does not directly affect the change or the emergence of the dependent variable. The intervening variable in this study is Interest in Using.

\section{Research Population}

According to Sugiyono (2016: 80) the population is the area of generalization, objects / subjects that have certain qualities and characteristics determined by researchers to be studied and then drawn conclusions. The population in this study were students in the city of Semarang. Research Samples. According to Sugiyono (2016: 81), the sample is part of the number and characteristics of the population. The number of students in the city of Semarang is unknown and the number of students in the city of Semarang who have done online shopping using Instagram social media services is also unknown. Then the number of samples is determined as much as possible based on the opinion of Ferdinand (2002) in Hanggono, et al (2015), which states that the number of samples is determined by the number of indicators multiplied by five to ten. This study uses 13 indicators so the figures calculated according to this study are 13 indicators $\mathrm{x} 5$ respondents $=65$ respondents.

\section{Result and Discussion}

\section{Validity test}

According to Ghozali (2011: 52-59), measuring validity can be done by correlating the score of questions with the total construct score or variable. Significance test is done by comparing the value of $r$ arithmetic with $r$ table for degree of freedom $(\mathrm{df})=\mathrm{n}-2$, in this case $\mathrm{n}$ is the number of samples. So the $\mathrm{df}$ used is $65-2=64$ with an alpha of $5 \%$, resulting in a table $r$ value (two-tailed test) of 0.242 with the following provisions: 1 . Results $r$ count $>r$ table $(0.242)=$ valid 2 . Results $r$ count $<$ r table $(0.242)=$ invalid, the following are the results of the validity test:

Table 1. Test the Validity of Perception Useful Variables

\begin{tabular}{ccccc}
\hline No. & $\begin{array}{c}\text { Questionnaire } \\
\text { statement }\end{array}$ & r Count & R table & Description \\
\hline 1. & Item 1 & 0.621 & 0.242 & Valid \\
2. & Item 2 & 0.812 & 0.242 & Valid \\
3. & Item 3 & 0.732 & 0.242 & Valid \\
4. & Item 4 & 0.655 & 0.242 & Valid \\
5. & Item 5 & 0.759 & 0.242 & Valid \\
6. & Item 6 & 0.775 & 0.242 & Valid \\
\hline
\end{tabular}

Table 2. Test Validity of Ease Perception Variables

\begin{tabular}{ccccc}
\hline No. & $\begin{array}{c}\text { Questionnaire } \\
\text { statement }\end{array}$ & r Count & R table & Description \\
\hline 1. & Item 1 & 0.752 & 0.242 & Valid \\
2. & Item 2 & 0.657 & 0.242 & Valid \\
3. & Item 3 & 0.687 & 0.242 & Valid \\
4. & Item 4 & 0.664 & 0.242 & Valid \\
5. & Item 5 & 0.765 & 0.242 & Valid \\
6. & Item 6 & 0.785 & 0.242 & Valid \\
\hline
\end{tabular}


Table 3. Test the Validity of Interest Using Variables

\begin{tabular}{ccccc}
\hline No. & $\begin{array}{c}\text { Questionnaire } \\
\text { statement }\end{array}$ & r Count & R table & Description \\
\hline 1. & Item 1 & 0.877 & 0.242 & Valid \\
2. & Item 2 & 0.890 & 0.242 & Valid \\
\hline
\end{tabular}

Table 4. Test the Validity of Real Use Variables

\begin{tabular}{ccccc}
\hline No. & $\begin{array}{c}\text { Questionnaire } \\
\text { statement }\end{array}$ & r Count & R table & Description \\
\hline 1. & Item 1 & 0.571 & 0.242 & Valid \\
2. & Item 2 & 0.642 & 0.242 & Valid \\
3. & Item 3 & 0.727 & 0.242 & Valid \\
4. & Item 4 & 0.651 & 0.242 & Valid \\
5. & Item 5 & 0.782 & 0.242 & Valid \\
6. & Item 6 & 0.591 & 0.242 & Valid \\
7. & Item 7 & 0.618 & 0.242 & Valid \\
8. & Item 8 & 0.823 & 0.242 & Valid \\
9. & Item 7 & 0.486 & 0.242 & Valid \\
\hline
\end{tabular}

\section{Reliability Test}

In this testing, the researchers measure the relics a variable in the way of seeing the Alpha cronbaach. A constructive or variable is said relicable if giving an Alpha's rate of Alpha S rate of 0,60 (Ghozali, 2011: 48. Here is the result of the relicility that has been tested:

\begin{tabular}{|c|c|c|c|}
\hline No. & Variable & $\begin{array}{l}\text { Cronbach's } \\
\text { Alpha }\end{array}$ & Description \\
\hline 1. & $\begin{array}{l}\text { Usability } \\
\text { Perception }\end{array}$ & 0.819 & Reliabel \\
\hline 2. & Easy Perception & 0.808 & Reliabel \\
\hline 3. & Interest in Using & 0.729 & Reliabel \\
\hline 4. & Real Use & 0.828 & Reliabel \\
\hline
\end{tabular}

\section{Classic Assumption Test}

\begin{tabular}{|c|c|c|c|c|c|c|}
\hline \multicolumn{7}{|c|}{ Normality Test } \\
\hline & \multicolumn{3}{|c|}{ Tests of Normality } & \multicolumn{3}{|c|}{ Shapiro-Wilk } \\
\hline & Statistic & Df & Sig. & Statistic & df & Sig. \\
\hline Usability & .074 & 65 & $.200^{*}$ & .974 & 65 & .182 \\
\hline Ease & .106 & 65 & .068 & .947 & 65 & .008 \\
\hline Interest in using & .108 & 65 & .058 & .949 & 65 & .010 \\
\hline Real use & .107 & 65 & .061 & .979 & 65 & .349 \\
\hline
\end{tabular}

*. This is a lower bound of the true significance. a. Lilliefors Significance Correction

Can conclude that on kolmogorov's colouring test results of Kiran mirnov because it has a significant negative, 0.05 significance. Meaning this result shows normal distribution of a coordinated coincidence of kolmogorov Smirnov, if data data is smaller than 0,05 , then the data's not distributed.

\section{Multicollinearity Test}

To test multicollinearity by looking at the VIF value of each independent variable, if the VIF value $<10$, it can be concluded that the data are free from multicollinearity symptoms, Imam Ghozali (2011: 105-106) The following are the results of the multicollinearity test:
Table 7. Multicollinearity Test

\begin{tabular}{llllll}
\hline Model & & $\begin{array}{l}\text { Model I } \\
\text { Tolerance VIF }\end{array}$ & \multicolumn{2}{l}{$\begin{array}{l}\text { Model II } \\
\text { Tolerance VIF }\end{array}$} \\
\hline 1 & $\begin{array}{l}\text { (Contant) } \\
\text { Usability }\end{array}$ & .825 & 1.213 & .952 & 1.051 \\
& & & & & \\
& Ease & .820 & 1.220 & .952 & 1.051 \\
& Interest in using & .712 & 1.404 & & \\
\hline
\end{tabular}

a. Dependent Variable: Real Use

Based on table 7 above shows that the perception of usability, perceived ease of use and interest in Model I and the perceived usefulness variable, perceived ease in Model II has a tolerance value $\geq 0.100$ which means there is no correlation between independent 
variables. While the results of the calculation of Variance Inflation Factor (VIF) indicate that the variables of perceived usefulness, perceived ease of use and interest in Model I and the perceived usefulness variable, perceived ease of Model II has a VIF value of $\leq 10$ which means there is no correlation between independent variables. Based on tolerance and VIF values, it can be concluded that there is no multicollinearity between independent variables in the regression model I and the regression model II. From the multicollinearity symptoms with the assumption that each variable value $<10.00$.

\section{Heteroscedasticity Test}

If the variance from one observation residual to another observation is fixed, then it is called Homokedastisitas and if it is different is called Heteroscedasticity. The statistical test used in research is the Glejser Test. If significant independent $<0.05$ statistically affects the dependent variable, then there is an indication of Heteroscedasticity. If the significance occurs $>0.05$, then it can be concluded that the regression model does not contain Heteroscedasticity, Ghozali (2011: 139).

Table 8. Glejser Heteroscedasticity Test

\begin{tabular}{lll}
\hline & Model I Sig. & Model II Sig. \\
\hline 1 (Constant) & .886 & .283 \\
PU & .475 & .791 \\
PEOU & .219 & .579 \\
BITU & .503 & \\
\hline
\end{tabular}

a. Dependent Variable: RES3

From table 8 shows the results of the heteroscedasticity test of model I and model II. Of the significance values have met the assumptions If the significance of $>0.05$ does not contain the existence of heteroscedasticity. Then it can be concluded that the regression model does not contain heteroscedasticity.

\section{Regression Analysis}

In this study using simple and multiple linear regression analysis methods. This study will examine the direct effect and the indirect effect between the independent variable on the intervening variable and the independent variable, the intervening variable on the dependent variable, through the intervening variable and the results are as follows:

Table 9. Analysis of Regression Equations

Coefficients $^{\mathrm{a}}$

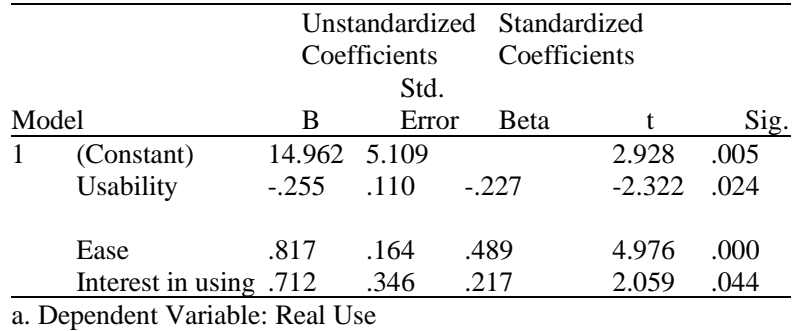

From table 9 it can be seen the effect between the independent variable and the intervening variable with the intervening variable. Following are the results of the regression equation obtained: $Y=14,962 \alpha-0,255 \mathrm{X} 1+$ $0,817 \mathrm{X} 2+0,712 \mathrm{Z}$.

a. The results of the regression analysis equation are as follows: The constant regression coefficient is known for 14,962. This means that the variable perceived usefulness, perceived ease of use and interest are considered constant, then the dependent variable is the real use of 14,962

b. The regression coefficient of usefulness perception variable is obtained by 0.225. This shows that there is a negative effect of perceived usefulness 
on real use. If the perceived usefulness is less then the real use of Instagram in making online purchases will decrease. Conversely, if the use can be felt, the real use will increase.

c. The regression coefficient of ease perception variable was obtained by 0.817. This shows that there is a positive effect of perceived ease of use. If the perceived ease is high, the real use will be even higher. Conversely the lower the perceived ease of use will actually be lower.

d. The regression coefficient of the variable using interest was obtained at 0.712. This shows that there is a positive influence of interest in the use of real use. If the interest in using is high then the real use will be even higher. Conversely the lower the interest in using the real use will be lower too.

Table 11. Determination Coefficient Test

\begin{tabular}{|c|c|c|c|c|c|}
\hline \multicolumn{6}{|c|}{ Coefficients $^{\mathrm{a}}$} \\
\hline \multirow[b]{4}{*}{ Model } & \multirow{3}{*}{\multicolumn{2}{|c|}{$\begin{array}{c}\text { Unstandardized } \\
\text { Coefficients } \\
\text { Std. }\end{array}$}} & \multirow{3}{*}{$\begin{array}{l}\text { Standardized } \\
\text { Coefficients }\end{array}$} & \multirow[b]{4}{*}{$\mathrm{t}$} & \multirow[b]{4}{*}{ Sig. } \\
\hline & & & & & \\
\hline & & & & & \\
\hline & $\mathrm{B}$ & Error & Beta & & \\
\hline $1 \quad$ (Constant) & 5.712 & 1.731 & & 3.300 & .002 \\
\hline PU &. .116 & .038 & -.340 & -3.092 & .003 \\
\hline PEOU & .177 & .056 & .347 & 3.160 & .002 \\
\hline
\end{tabular}

a. Dependent Variable: BITU

From table 11 it can be seen the effect between the independent variable and the intervening variable with the intervening variable. Following are the results of the regression equation obtained: $Z=5,712 \alpha$ $0,116 \mathrm{X} 1+0,177 \mathrm{X} 2$. The results of the regression analysis equation are as follows: a. The constant regression coefficient is known to be 5,712 . This means that the variable perceived usefulness, perceived convenience is fixed, then the variable use of interest is 14,962

b. The regression coefficient of usefulness perception variable is obtained by -0.116 . This shows that there is a negative effect of perceived usefulness on the interest in using. If the perceived usefulness is lacking then interest in using Instagram in making online purchases will decrease. Conversely, if the use can be felt, the real use will increase.

c. The regression coefficient of perceived ease of variables was 0.117 . This shows that there is a positive effect of perceived ease of use. If the perceived ease is high, the interest in using will be higher. Conversely the lower the perceived ease of use will be the lower interest too.

\section{Model Feasibility Test}

\section{Determination Coefficient Test}

The coefficient of determination test (R2) is used to measure how far the model's ability to explain variations in independent variables. The coefficient of determination is between 0 (zero) and 1 (one). If the value of R2 is small, it means that the ability of the independent variables in explaining the dependent variable is very limited. If the value of R2 is close to 1 , it means that the independent variables provide almost all the information needed to predict variations in the dependent variable, Ghozali (2011: 97). Here are the results of the coefficient of determination test: 
Model I shows an R Square value of 0.517 , this shows that $51.7 \%$ of the independent variables and intervening variables are able to explain the dependent variable. The variable of perceived usefulness, perceived ease of use and interest are able to explain the real use variable, while the remaining $49.3 \%$ is explained by other variables not examined in this study. Model II shows an R Square value of 0.288 , this means that $28.8 \%$ of the independent variables are able to explain the intervening variable. The variable of perceived usefulness and perceived ease of being able to explain the intervening variable is the use of interest while the remaining $72.2 \%$ is explained by other variables not examined in this study.

\section{Simultan Test (f)}

The significance level of the $F$ test can be seen from the significant number. If the value of sig $<\alpha$ (alpha), then there is an influence together (simultaneously) independent variables on the dependent variable. This test uses a significance level of $0.05(\alpha=5 \%)$. Ghozali (2011: 98).

\section{Table 12. Simultan Test}

\begin{tabular}{lll}
\hline ANOVA $^{\mathrm{a}}$ & & \\
Model & F & Sig. \\
\hline I & 21.788 & $.000^{\mathrm{b}}$ \\
II & 12.522 & $.000^{\mathrm{b}}$
\end{tabular}

a. Dependent Variable: Real Use and Interest in using

b. Predictors: (Constant), Perception of Use, Perception of Ease, Interest in Using (I) and Perception of Usefulness, Perception of Ease (II)

Based on Table 12. In model I can be concluded that the perception of usefulness, perceived ease of use and interest in real use has a significance value of $0,000<0.05$ and $f$ count is 21,788 , then simultaneously the variable perception of usefulness, perceived ease of use and interest has a significant effect against actual use in other words $\mathrm{HO}$ is rejected and $\mathrm{Ha}$ is accepted. In model II it can be concluded that the variable that perceptions of usefulness, perceptions of ease of interest in using has a significance value of $0,000<0.05$ and $f$ arithmetic of 12.522 , then simultaneously perceptions of usefulness, perceptions of significant ease of interest using in other words $\mathrm{HO}$ is rejected and $\mathrm{Ha}$ accepted.

Table 13. Partial Test (T)

\begin{tabular}{|c|c|c|c|c|c|}
\hline \multicolumn{6}{|c|}{ Coefficients $^{\mathrm{a}}$} \\
\hline \multirow[b]{4}{*}{ Model } & \multirow{3}{*}{\multicolumn{2}{|c|}{$\begin{array}{c}\text { Unstandardized } \\
\text { Coefficients } \\
\text { Std. }\end{array}$}} & \multirow{3}{*}{$\begin{array}{c}\text { Standardized } \\
\text { Coefficients }\end{array}$} & \multirow[b]{4}{*}{$\mathrm{t}$} & \multirow[b]{4}{*}{ Sig. } \\
\hline & & & & & \\
\hline & & & & & \\
\hline & B & Error & Beta & & \\
\hline (Constant) & 5.712 & 1.731 & & 3.300 & .002 \\
\hline usability & -.116 & .038 & -.340 & -3.092 & .003 \\
\hline Ease & .177 & .056 & .347 & 3.160 & .002 \\
\hline
\end{tabular}

This test aims to determine whether or not the influence of each independent variable on the dependent variable. $\mathrm{T}$ test is used to verify the truth or error of the hypothesis. To determine the significance of the $t$ test is to see a significant number to make a decision that is if significant $t<0.05$ and the beta coefficient is unidirectional then the hypothesis is accepted, whereas if the significance of $t>0.05$ and the beta coefficient is not unidirectional then the hypothesis is rejected. Ghozali (2011: 98). Following are the partial test results $(\mathrm{t})$ :

1. Based on the partial test table $(\mathrm{t})$ can be explained as follows: Usability perception variable has a regression coefficient of -0.116 and a significance value of 0.003 . This shows that the usability perception variable has 
a negative and significant effect because the regression coefficient is negative and the significance value is below 0.050 . Thus the hypothesis stating that perceived usefulness does not have a positive effect on interest in using ACCEPTED.

2. The perceived ease variable has a regression coefficient of 0.177 and a significance value of 0.002 . This shows that the perception of convenience variable has a positive and significant effect because the value of the positive regression coefficient and the significance value are below 0.050 . Thus the hypothesis stating that perceived ease has a positive effect on interest in using ACCEPTED.

Table 14. Partial Test (T)

\begin{tabular}{|c|c|c|c|c|c|}
\hline \multicolumn{6}{|c|}{ Coefficients $^{\mathrm{a}}$} \\
\hline \multirow[b]{4}{*}{ Model } & \multirow{3}{*}{\multicolumn{2}{|c|}{$\begin{array}{l}\text { Unstandardized } \\
\text { Coefficients }\end{array}$}} & $\begin{array}{c}\text { Standard } \\
\text { ized }\end{array}$ & \multirow[b]{4}{*}{$\mathrm{t}$} & \multirow[b]{4}{*}{ Sig. } \\
\hline & & & Coefficie & & \\
\hline & & & & & \\
\hline & B & Error & Beta & & \\
\hline $1 \quad$ (Constant) & 14.962 & 5.109 & & 2.928 & .005 \\
\hline usability &. .255 & .110 & .227 & -2.322 & .024 \\
\hline Ease & .817 & .164 & .489 & 4.976 & .000 \\
\hline $\begin{array}{l}\text { interest in } \\
\text { using }\end{array}$ & .712 & .346 & .217 & 2.059 & .044 \\
\hline
\end{tabular}

a. Dependent Variable: Real Use

1. Based on the sobel test results for Model I and Model II above shows that: T value calculated compared to the value of $t$ table that is equal to 1,989. If the calculated $t$ value is greater than the $t$ table value, it can be concluded that there is a mediation effect. And the result of $t$ count is -2.2886 , then $t$ count is smaller than $\mathrm{t}$ table and it can be concluded that the hypothesis states that the perception of usefulness does not affect the real use through interest in using as an intervening variable ACCEPTED.

2. T value calculated compared to the value of $t$ table that is equal to 1,989. If the calculated $t$ value is greater than the $t$ table value, it can be concluded that there is a mediation effect. And the result of $\mathrm{t}$ arithmetic is 2.0332 , then $t$ arithmetic is greater than $t$ table and it can be concluded that the hypothesis which states that the perception of ease has a positive effect on real use through interest using as an intervening variable ACCEPTED.

\section{Conslution}

The calculation results obtained show that the perception of usability variable towards real use has a negative effect. This shows that the less perceived usefulness of consumers on the online shop Instagram social networking site, then the real use of Instagram in online purchases will decrease. The calculation shows that the perceived ease of use variable has a real positive effect. This shows that the higher the level of convenience that consumers get on the online shop social networking site Instagram, the real use of Instagram in online purchases will increase. From the calculation results show that the variable usability perception of interest in using has a negative effect. This shows that the lower the level of benefits obtained by consumers on the online shop social networking site Instagram, the interest in 
using it will also decrease. From the calculation results show that the variable perception of usefulness of interest in using has a negative influence. This shows that the lower the level of benefits obtained by consumers on the online shop social networking site Instagram, the interest in using it will also decrease. From the calculation results obtained indicate that the variable of interest using the real use has a positive effect. This shows a significant positive effect on the real conditions of use, meaning that the higher the interest in using Instagram, the higher the reality of using Instagram in online purchases. From the calculation obtained shows the perception of the use of real use with interest to use as an intervening variable that the value of $r$ table obtained is greater than $r$ arithmetic, meaning that in this hypothesis the effect is indirectly negative effect. From the results of the hypothesis obtained, the perception of usability of real use with the interest in using as an intervening variable results in $r$ count greater than $r$ table, that indirectly there is a positive influence on perceived ease of use with the interest in using as an intervening variable.

\section{References}

\section{Journal}

Arafat Shahed \& Saba Tanzila. (2016). Social Media Marketing Vs Social Media Commerce: a Study of Social Media's Effectiveness on Increasing Businesses' Sales. Journal of Business and Technovation, 4(3(ISSN: 2414-245X), 134-145.

Perangin-angin Widia Afriani, Agustini Dyah
Respati dan Maharani Dhian Kusumawati. (2016). Pengaruh Perceived Usefullness dan Perceived Ease of Use terhadap Attitude Toward Using E-Faktur. Journal of Research in Ecomonics and Management, Volume 16, No. 2, 307-322.

Alomary, A., \& Woollard, J. (2015). How is Technology Accepted By Users? A Review of Technology Acceptance Models and Theories. Proceedings of The IRES 17th International Conference, London, United Kingdom, 1-4 978-93-85832-48-2.

Arief Wibowo. (2018). Kajian Tentang Perilaku Pengguna Sistem Informasi Dengan Pendekatan Technology Acceptance Model (TAM). Jakarta Selatan: Program Studi Sistem Informasi, Fakultas Teknologi Informasi Universitas Budi Luhur.

Azuan Hashim Noor. (2017). Embracing the Instagram Waves - The New Business Episode to the Potential Entrepreneurs. Journal of Entrepreneurship and Business Innovation, 13-29.

Bayu \& Nugraha. (2012). Perilaku Komunikasi Pengguna Aktif Instagram.

Davis Fred D. (1980). A Technology Acceptance model For Empirically Testing New End-User Information Systems: Theory and Results. Industrial Engineering, Wayne State University.

Fischer E. (2011). Social interaction via new social media: how can interactions on Twitter affect effectual thinking and behaviour. Journal of Business 
Venturing, 26 (1), 1-18.

Fishbein Martin \& Ajzen Icek. (1975). Belief Attitude Intention and Behavior. Adisson Wesley Publishing Company.

Ghozali Imam. (2011). Aplikasi Analisis Multivariate Dengan Program SPSS. Semarang: Badan Penerbit Universitas Diponegoro.

Hanggono Aditya Arie, Siti Ragil Handayani, Heru Susilo. (2015). Analisis atas Praktek TAM (Technology Acceptance Model) Dalam Mendukung Bisnis Online dengan Memanfaatkan Jejaring Sosial Instagram. Jurnal Administrasi Bisnis, Vol. 26 No. 1, 1-9.

Indrajit Richardus Eko. (2001). E-Commerce: Kiat dan Strategi Bisnis di Dunia Maya. Jakarta: PT Elex Media Komputindo.

Indrayana Bayu, Kudang Boro Seminar, dan Bagus Sartono. (2016). Faktor Penentu Minat Penggunaan Instagram Untuk Pembelian Online Menggunakan TechnologyAcceptance Model (TAM) dan TheoryofPlanned Behavior (TPB). Jurnal Aplikasi Bisnis dan Manajemen, 2 No. 2(E-ISSN: 2460-7819), 138-147.

Jogiyanto. (2008). Sistem Indormasi Kperilakuan. Yogyakarta: Andi.

Khakim Kharisma Nur. (2011). Analisis Faktor-faktor yang Mempengaruhi Penerimaan dan Penggunaan Software Akuntansi MYOB Dengan Menggunakan Pendekatan Technology Acceptance Model (TAM). Fakultas Ekonomi Universitas Diponegoro Semarang.

Magie, Anna Ashlock. (2008). An Analysis of Lifestyle, Shopping Orientations,
Shopping Behaviors and Shopping Involvement Among Teens Aged 13 to 18 in The United States. ProQuest Dissertations and Theses.

Mujiyana, Ingge Elissa. (2013). Analisis Faktor - Faktor yang Mempengaruhi. J@TI Undip, Vol VIII, No 3, 143-152.

Nasri Wadie \& Charfeddine Lanouar. (2012). Factors affecting the adoption of Internet banking in Tunisia: An integration theory of acceptance model and theory of planned behavior. The Journal of High Technology Management Research, Volume 23(1), $1-14$.

Novianti Astrid Widya, Dudi Pratomo, \& Kurnia. (2017). Faktor Penentu Minat Penggunaan Instagram Untuk Pembelian Onine Menggunakan Technology Acceptance Model (TAM). e-Proceeding of Management, Vol.4, No.2(ISSN : 2355-9357), 1628-1636.

Selwendri dan Rumyeni. (2016). Implementasi Technology Acceptance Model dalam Aktivitas Belanja Online Melalui Media Sosial Instagram di Kalangan Mahasiswa Universitas Sumatera Utara. Jurnal Aplikasi Bisnis, Vol. 7 No. 1, 76-103.

Sugiyono. (2016). Metodologi Penelitian Kuantitatif, Kualitatif, dan R\&D. Bandung: CV Alfabeta.

Venkatesh Viswanath \& Davis Fred D. (2000). A Theoretical Extension of the Technology Acceptance Model: Four Longitudinal Field Studies. Management Science, Vol. 46, No. 2, February(1526-5501 electronic ISSN), 186-204. 
Walker RH, LW Johnson, S Leonard. (2006). Re-thinking the conceptualization of customer value and service quality within the service-profit chain. Managing Service Quality, 23-36.

Wida Putu Ayu Mira Witriyanti, Ni Nyoman Kerti Yasa,I Putu Gde Sukaatmadja. (2016). Aplikasi Model TAM (Technology Acceptance Model) Pada
Perilaku Pengguna Instagram.

Universitas Udayana. 
Journal of Digital Marketing And Halal Industry

Vol. I, No. I (2019) 61-74

http://journal.walisongo.ac.id/index.php/JDMHI/index http://dx.doi.org/10.21580/jdmhi.2019.1.1.4760 